\title{
Deteksi Penyakit Pada Tanaman Mangga Dengan Citra Digital : Tinjauan Literatur Sistematis (SLR)
}

\author{
Solikin ${ }^{1, *}$ \\ ${ }^{1}$ Sistem Informasi; Universitas Bina Insanl; Jl. Siliwangi No 6 Rawa Panjang Bekasi Timur \\ 17114 Indonesia. Telp. (021) 82436886 / (021) 82436 996. Fax. (021) 824009 24; e-mail: \\ solikin@binainsani.ac.id \\ * Korespondensi: e-mail: solikin@binainsani.ac.id
}

Diterima: 15 April 2020; Review: 21 April 2020; Disetujui: 26 April 2020

Cara sitasi: Solikin,2020. Deteksi Penyakit Pada Tanaman Mangga dengan Citra Digital : Tinjauan Literatur Sistematis. Bina Insani ICT Journal. Vol.7 (1): 63-72.

\begin{abstract}
Abstrak: Penelitian dengan melakukan tinjauan literatur sistematis (Sistematic Literatur Review-SLR) dilakukan untuk mempelajari berbagai teknik identifikasi penyakit pada daun dengan citra digital sebagai tahapan untuk mendapatkan pemahaman mengenai teknik identifikasi penyakit pada daun mangga dengan citra digital. Produksi Mangga di Indonesia dari tahun 2014 - 2018 secara fluktuatif selalu mengalami peningkatan dan di tahun 2018 produksi mangga di Indonesia mencapai 2.624 .783 ton, proses budidaya tanaman mangga tidak selamanya dapat terlepas dari serangan penyakit. Penyakit pada tanaman mangga disebabkan oleh jamur atau bakteri yang biasanya menyerang pada bagian akar, batang, kulit batang, ranting atau buah mangga. Jenis penyakit pada tanaman mangga adalah : Penyakit mangga (Jamur Gloesoporium), Penyakit Diplodia, Cendawan jelaga, Bercak karat merah, Kudis buah, Penyakit Blendok. Penyakit pada mangga memiliki berbagai gejala dan kadang sulit didiagnosis oleh petani dan untuk itu diperlukan keahlian untuk mendiagnosis penyakit pada tanaman mangga dan bagaimana cara penanggulangannya yang biasanya keahlian tersebut terdapat pada ahli patologi tanaman professional. Sehingga dibutuhkan suatu Teknologi IT dengan Sistem Cerdas yang dirancang untuk dapat mengidentifikasi secara otomatis penyakit tanaman mangga dan cara penanggulangannya berdasarkan gejala visual dengan menggunakan metode citra digital. Metode literatur review yang digunakan yaitu Compare, Contrast, Criticize, Synthesize dan Summarize. Metode Citra Digital yang dapat digunakan dalam identifikasi penyakit pada daun mangga adalah tahapan Image Acquisition, Preprocessing, Segmentation, Ekstraksi Fitur, Seleksi Fitur. Metode Klasifikasi yang dapat digunakan adalah SVM, Artificial Neural Network, Decision Tree, Convolutional Neural Network.
\end{abstract}

Kata kunci: citra digital, daun, penyakit mangga, tinjauan literatur sistematis

Abstract: Research by conducting a systematic literature review (Systematic Literature Review$S L R$ ) was conducted to study various techniques of disease identification in leaves with digital images as a stage to gain an understanding of the techniques for disease identification on mango leaves with digital images. Mango production in Indonesia from 2014 - 2018 fluctuations has always increased and in 2018 mango production in Indonesia reached 2,624,783 tons, the process of mango cultivation is not always free from disease. Diseases of mango plants are caused by fungi or bacteria that usually attack the roots, stems, bark, twigs or mangoes. Types of diseases in mango plants are: Mango disease (Gloesoporium Fungus), Diplodia disease, sooty fungus, red rust spots, fruit scabies, Blendok disease. Diseases of mangoes have a variety of symptoms and are sometimes difficult to diagnose by farmers and expertise is needed to diagnose diseases on mango plants and how to overcome them which are usually found in professional plant pathologists. So that we need an IT Technology with an Intelligent System that is designed to be able to automatically identify mango plant diseases and how to overcome 
them based on visual symptoms using digital image methods. The literature review method used is Compare, Contrast, Criticize, Synthesize and Summarize. Digital image methods that can be used in the identification of diseases on mango leaves are the stages of Image Acquisition, Preprocessing, Segmentation, Feature Extraction, Feature Selection. Classification methods that can be used are SVM, Artificial Neural Network, Decision Tree, Convolutional Neural Network.

\section{Keywords: digital image, leaf, mango disease, systematic literature review}

\section{Pendahuluan}

Penelitian dengan melakukan tinjauan literatur sistematis dilakukan untuk mempelajari berbagai teknik identifikasi penyakit pada daun dengan citra digital sebagai tahapan untuk mendapatkan pemahaman mengenai teknik identifikasi penyakit pada daun mangga dengan citra digital.

Produksi Mangga di Indonesia dari tahun 2014 - 2018 secara fluktuatif selalu mengalami peningkatan dan di tahun 2018 produksi mangga di Indonesia mencapai 2.624 .783 ton [12]. Sehingga Mangga (Mangifera Indica) merupakan salah satu komoditas buah yang sangat populer dan juga menjadi salah satu komoditas ekspor. Sentra Perkebunan Mangga yang menjadi pusat-pusat produksi buah mangga pun tersebar di 34 propinsi di Indonesia [12].

Proses budidaya tanaman mangga tidak selamanya dapat terlepas dari serangan penyakit dan hama. Jenis penyakit yang menyerang tanaman dapat dilihat dari gejala-gejala serangan yang timbul. Penyebab penyakit tanaman mangga secara umum di sebabkan oleh Parasit dan Non-Parasit. Penyebab penyakit parasit terdiri dari patogen, hama dan gulma sedangkan penyebab penyakit non-parasit antara lain karena faktor air, suhu, cahaya dan nutrisi.

Penyakit patogen antara lain virus, bakteri, jamur dan chromista. Penyakit hama antara lain kutu, siput, mamalia dan tikus. Penyakit gulma antara lain monotil dan dikotil. Penyakit jamur (jamur gloesoporium) atau bakteri yang biasanya menyerang pada bagian akar, batang, kulit batang, ranting atau buah mangga dan daun. Hama pada tanaman mangga disebabkan oleh kepik mangga (cryptorrhynoccus gravis), hama bubuk buah mangga, lalat buah, wereng (idiocerus clypealis, idiocerus niveosparsus, idiocerus atkinsoni), tungau (paratetranychus yothersi, hemitarsonemus latus) dan codot.

Kepik mangga (cryptorrhynoccus gravis), biasanya buah yang di serang dan masuk ke bagian dalam buah. Bubuk buah mangga, menyerang buah mangga sampai ke tunas muda, cirinya kulit buah mangga kelihatan normal, akan tetapi jika dibelah maka akan terlihat bagian dalam mangga dimakan oleh hama jenis ini. Lalat buah, tandanya buah mangga busuk, jatuh dan akibatnya dapat menurunkan produktivitas. Wereng (idiocerus clypealis, idiocerus niveosparsus, idiocerus atkinsoni) jenis wereng ini agak berbeda dengan yang menyerang tanaman padi, wereng ini biasanya menyerang daun mangga, rangkaian bunga serta ranting dan mengeluarkan cairan manis yang dampaknya mengundang semut api untuk memakan tunas serta kuncup, sifat cairanny yang membeku akan menimbulkan jamur kerak hitam. Tungau (paratetranychus yothersi, hemitarsonemus latus), awalnya yang diserang adalah daun mangga muda dan selanjutnya menyerang permukaan daun mangga dibagian bawah, dimana keduanya akan menyerang rangkaian bunga mangga.

Penyakit diplodia, jamur diplodia sp, akan menimbulkan luka tanaman muda mangga hasil okulasi. Cendawan jelaga, diakibatkan oleh virus mliola mangifera (jamur capmodium mangiferum), biasanya daun mangga yang diserang mengakibatkan berwarna hitam mirip seperti beledu, warna hitam tersebut disebabkan oleh jamur yang hidup didalam cairan manis. Bercak karat merah, di sebabkan oleh jamur colletotrichum gloeosporiodes, biasanya menyerang daun, ranting, bunga serta tunas mangga sehingga terbentuk bercak berwarna merah. Kudis buah, biasanya menyerang tangkai bunga, bunga, ranting dan daun mangga, ciri gejalanya antara lain di sebabkan adanya bercak warna kuning yang berubah menjadi warna abu-abu. Penyakit Blendok, disebabkan oleh antara lain jamur diplodia recifensis yang hidup di dalam bagian lubang akibat kumbang Xyleborus affinis), dimana lubang akan mengeluarkan getah yang menyebabkan warna berubah menjadi coklat atau hitam.

Gulma, merupakan benalu yang akan memberikan kerusakan dalam waktu cepat dan akan menyebabkan makanan tidak dapat diserap tanaman mangga secara sempurna.[5]. Secara umum penyebab peyakit pada tanaman mangga dapat dilihat pada gambar 1 . 


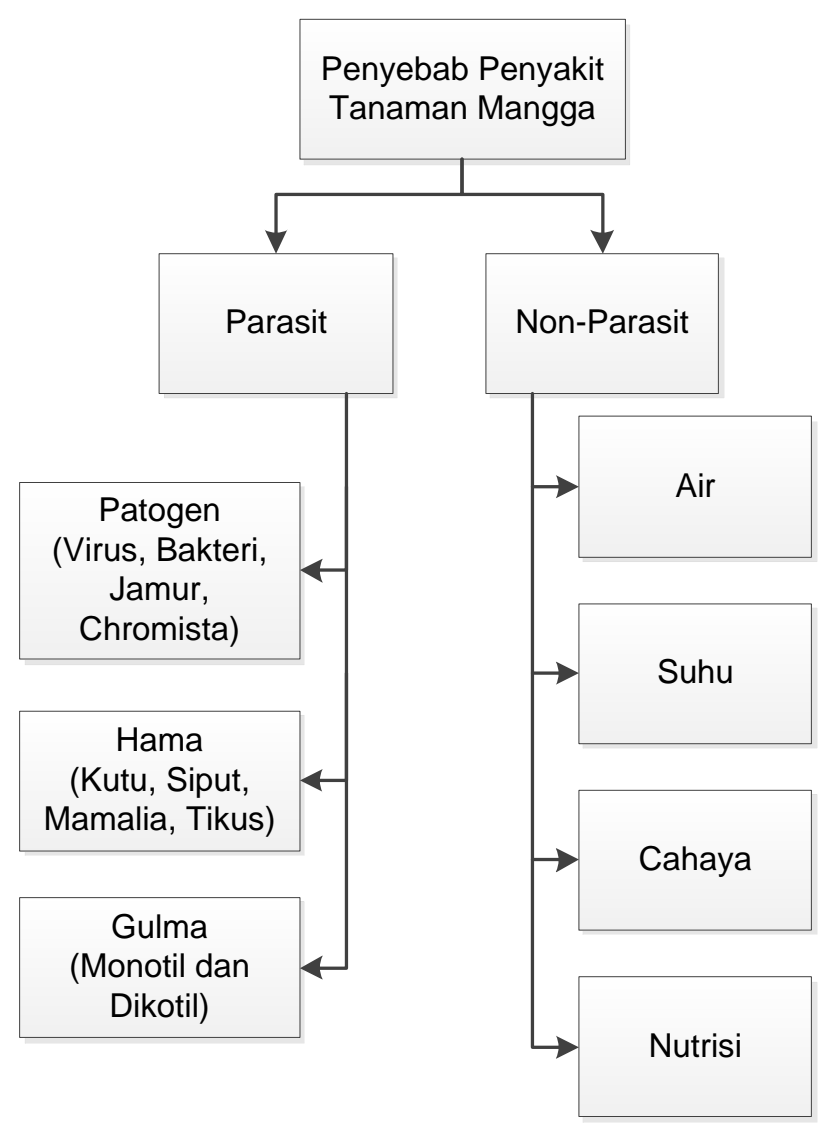

Sumber : Hasil Penelitian (2020)

Gambar 1. Gambaran Umum Penyebab Penyakit pada tanaman Mangga

Penyakit pada mangga memiliki berbagai gejala dan kadang sulit didiagnosis oleh petani [2] dan untuk itu diperlukan keahlian untuk mendiagnosis penyakit pada tanaman mangga dan bagaimana cara penanggulangannya yang biasanya keahlian tersebut terdapat pada ahli patologi tanaman professional. Sehingga dibutuhkan suatu Sistem Cerdas berbasis Teknologi IT yang dirancang untuk dapat mengidentifikasi secara otomatis penyakit daun mangga dan cara penanggulangannya berdasarkan gejala visual dengan menggunakan metode citra digital.

Berdasarkan uraian tersebut diatas, maka dalam penelitian ini akan melakukan tinjauan literatur sistematis untuk mengidentifikasi, menilai, dan menginterpretasi penelitian yang terkait dengan penyakit pada daun dan daun mangga pada khususnya dengan menggunakan citra digital.

\section{Metode Penelitian}

Metode penelitian yang dilakukan pada penelitian ini adalah melakukan tinjauan literatur sistematis untuk mengetahui metode yang digunakan oleh para peneliti dalam mengidentifikasi suatu penyakit pada daun dengan menggunakan Citra Digital. Tahapan yang dilakukan dalam penelitian ini adalah Mencari kesamaan (Compare), Mencari ketidaksamaan (Contrast), Memberikan pandangan (Criticize), Membandingkan (Synthesize) dan Meringkas (Summarize) [10].

Mencari Kesamaan (Compare); teknik melakukan review dengan cara mencari kesamaan diantara beberapa literatur dan diambil kesimpulannya. Mencari Ketidaksamaan (Contrast); teknik melakukan review dengan cara menemukan perbedaan diantara beberapa literatur dan diambil kesimpulannya. Memberikan Pandangan (Criticize); teknik melakukan review dengan membuat pendapat sendiri terhadap sumber yang dibaca.Membandingkan (Synthesize); teknik melakukan review dengan menggabungkan beberapa sumber menjadi 
sebuah ide baru. Meringkas (Summarize); teknik melakukan review dengan menulis kembali sumbernya dengan kalimat sendiri.

Sehingga penulis dapat mengetahui apa saja tahapan penelitian, teknik, metode atau algoritma yang dapat digunakan dalam penelitian selanjutnya.

\section{Hasil dan Pembahasan Citra Digital}

Merupakan proses pengambilan citra dari obyek yang akan diteliti. Citra dapat dibedakan menjadi Citra analog dan Citra digital. Dari sisi konten visual, citra dapat dibedakan menjadi citra berwarna, citra grey level dan citra biner. Pada penelitian ini Citra yang digunakan adalah citra digital. Citra berwarna adalah citra yang secara visual memiliki kandungan informasi warna yang dipresentasikan dalam nilai-nilai piksel yang mengandung komponen luminance, hue dan chrominance/saturation.

Pada pemrosesan Citra dapat dilakukan dengan menggunakan berbagai ruang warna, sesuai dengan domain aplikasi. Ruang warna yang digunakan selain RGB adalah CMYK, HSV, HSL, Lab, Luv, YCbCr dan HCL.[7]

\section{Format Citra}

Format file citra standar yang banyak digunakan saat ini antara lain BMP, TIFF, GIF, PNG, JPEG dan JPEG 2000. Standard JPEG ( Joint Photographic Experts Group) menentukan codec ( coding and decoding) yang mendefinisikan bagaimana sebuah citra dikompresi ke dalam bitstream dan didekompresi kembali ke dalam bentuk citra. Rasio kompresi JPEG relative besar (ukuran file hasil kompresi jauh lebih kecil disbanding dengan file asli), dengan kualitas citra rekonstruksi yang tetap baik.[7]

\section{Sistem Identifikasi Penyakit Pada Daun Dengan Pengolahan Citra Digital}

Secara umum sistem identifikasi penyakit pada daun menggunakan inputan berupa gambar yang diambil dengan menggunakan kamera digital. Gambar yang didapat dikirimkan ke komputer untuk diproses dan dianalisis. Gambar yang ada lalu diproses dengan image processing algorithm untuk didapatkan informasi yang berkualitas. Secara garis besar tahapan proses dalam sistem Identifikasi Penyakit pada Daun dengan pengolahan citra digital ditunjukkan pada gambar 2.

Gambar / Image Daun - Obyek yang ada disini adalah Daun diambil citranya oleh alat yaitu kamera dan diubah menjadi gambar. Hasil atau gambar kemudian dikirim ke komputer untuk diproses lebih lanjut.

Pre-Processing - Langkah ini menghilangkan gangguan dan meningkatkan kontras gambar. Ada dua tipe pendekatan untuk preproses dalam mengevaluasi suatu citra berdasarkan ukuran piksel tetangga yang digunakan untuk menghitung sebuah piksel baru. Preproses berdasarkan nilai piksel melihat citra secara piksel-ke-piksel sebagai satu nilai unik, yang berdiri sendiri tanpa dipengaruhi oleh nilai tetangganya. Metode preproses yang lainnya adalah local preprocessing yang lebih dikenal dengan filter. Filter terdapat dua jenis yaitu highpass filter dan lowpass filter, highpass filter digunakan untuk meningkatkan intensitas yang paling tinggi dari sekitarnya, sedangkan lowpass filter adalah sebaliknya yaitu menghilangkan intensitas yang lebih tinggi. Untuk menghilangkan noise biasanya digunakan lowpass filter, seperti mean filter dan gaussian filter. Gaussian bekerja sebagai filter yang memandang dua aspek citra, yaitu domain spasial (jarak antar piksel) dan domain wilayah (frekuensi dalam satu wilayah).

Segmentasi - Tahap ini membagi gambar ke wilayah kepentingan. Metode segmentasi citra terdiri dari beberapa pendekatan,yaitu berbasiskan pada nilai threshold, wilayah, nilai gradien, dan metode klasifikasi piksel. Segmentasi berbasis threshold akan efektif untuk objek yang memiliki warna yang mendekati homogen dan memiliki wilayah-wilayah yang nilai intensitas kelompoknya jauhberbeda satu sama lain. Teknik ini seringkali harus diawali dengan peningkatan kualitas citra secara maksimal. Metode ini sangat cocok untuk data yang mengandung banyak noise dan variasi transformasi citra seperti translasi, rotasi, dan perubahan struktur. Segmentasi berbasis wilayah ( Region Based) terbagi atas dua ketegori yaitu region growing and merging (GM) dan Region splitting and merging (SM). GM melakukan grouping dari satu atau dua piksel lalu membentuk wilayah yang lebih besar sampai ada 
wilayah yang memiliki tingkat homogenitas tertentu. SM membahi citra ke dalam wilayah yang lebih kecil sampai dengan nilai pembagi tertentu. Metode ini memiliki kompleksitas yang tinggi sehingga butuh proses lebih lama disbanding metode yang lain tetapi menghasilkan tingkat presisi yang baik. Metode Berbasis nilai gradient menghasilkan deteksi tepi dari citra. Metode ini cocok untuk data yang mengandung banyak noise dan variasi transformasi citra seperti translasi, rotasi dan perubahan struktur. Segmentasi berbasis klasifikasi, yang memisahkan masing-masing piksel kedalam objek yang berbeda berdasarkan perhitungan statistik untuk mengetahui tingkat kemiripan satu piksel dengan yang lainnya.

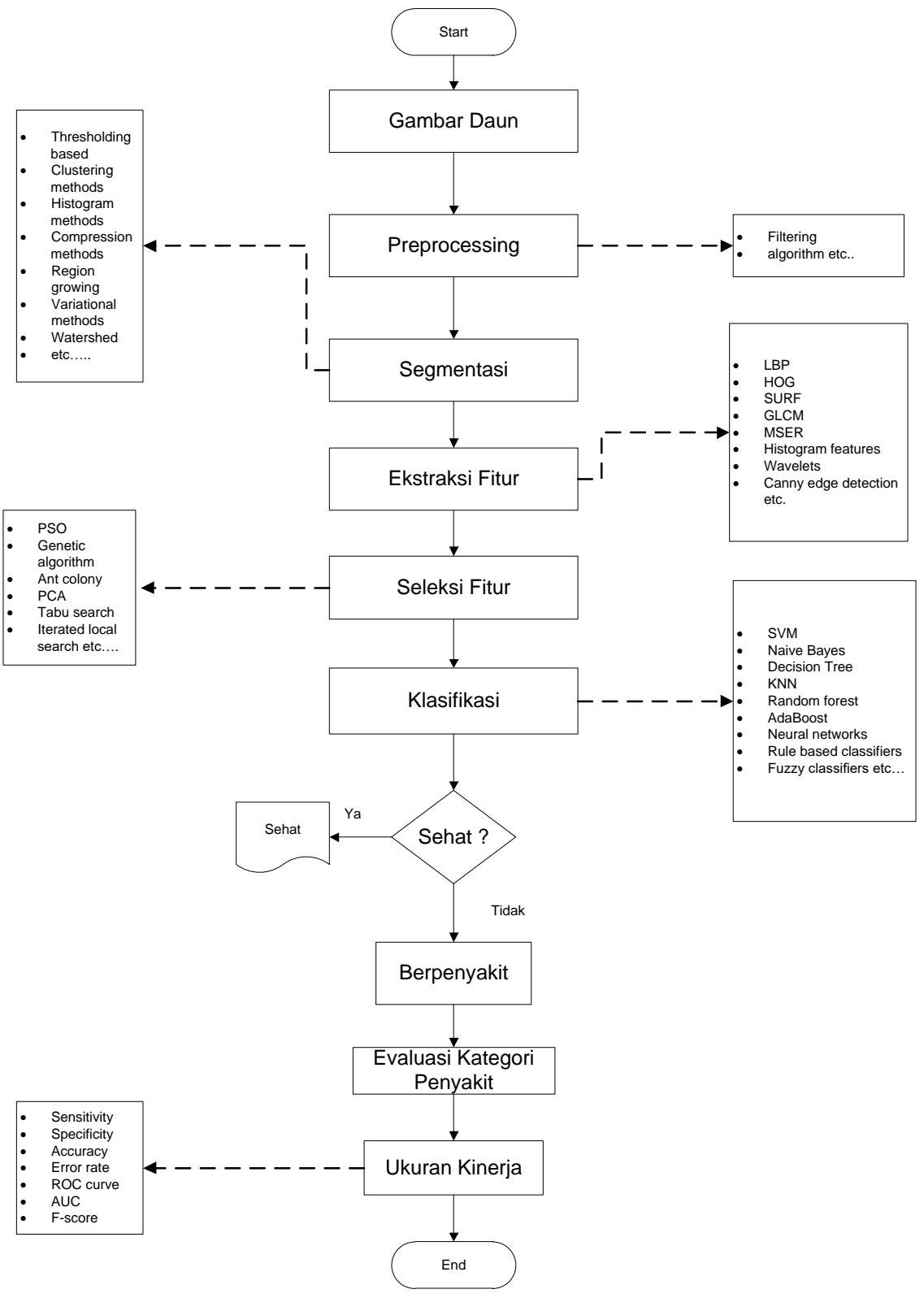

Sumber : Hasil Penelitian (2020)

Gambar 2. Tahapan Identifikasi dan Klasifikasi Penyakit pada Daun

Ekstraksi Fitur - proses meng-ekstrak fitur dari gambar atau obyek untuk menentukan ciri sebuah obyek dalam hal ini bagian dari daun yang akan diproses. Metode yang digunakan pada tahapan ini adalah Histogram, Wavelet, Cany Edge. Metoda Histogram. Metode Histogram merupakan metode banyaknya batang warna yang terbentuk, atau menunjukkan hasil jumlah pembagian rentang warna pada histogram. Metode Wavelet dapat digunakan untuk melakukan ekstraksi fitur karena dapat melakukan proses penguraian atau dekomposisi 
ruang vektor. Metode Canny Edge Detection (Deteksi Tepi Canny) merupakan deteksi algoritma tepi, ditemukan serta dikembangkan oleh John F. Canny tahun 1986.

Seleksi Fitur - Menentukan fitur yang sesuai untuk di proses. Pada tahapan ini, algoritma yang biasa digunakan adalah PSO, PCA, Genetic algoritma, Ant Colony, Iterated Local search.[7]. Algoritma Particle Swarm Optimization (PSO) adalah adalah salah satu algoritma optimasi yang dapat digunakan untuk pengambilan keputusan. Algoritma Principal Component Analysis (PCA) adalah metode yang digunakan untuk mengolah gambar wajah manusia yang akan secara otomatis sistem dapat mengenali wajah melalui ciri atau bagian utamanya seperti mata, hidung, bibir dan alis sebagai identitas. Algortima Genetika yang merupakan bagian dari Evolutionary Algorithm adalah algortima yang memanfaatkan proses seleksi alamiah yang lebih di kenal dengan evolusi. Algortima Ant Colony adalah suatu teknik probabilitas dalam menyelesaikan suatu permasalahan, yang mendasarkan pada tingkah laku semut didalam sebuah koloni yang menemukan atau mencari sumber makanan, algortima ant colony pada umumnya digunakan untuk menyelesaikan discrete optimization problems dan persoalan kompleks yang memiliki banyak variabel. Algoritma Iterated Local search adalah modifikasi pencarian lokal atau metode mendaki bukit dalam memecahkan masalah optimasi diskrit.

Klasifikasi - Langkah ini bertujuan untuk menentukan jenis penyakit pada daun. Classification bertujuan untuk mengidentifikasikan kategori dari satu objek. Hal tersebut berdasarkan data set yang telah dilatih terlebih dahulu melalui observasi terhadap karakteristik dari setiap group. Metode Classification yang sering digunakan adalah statistik, pohon keputusan, dan jaringan syaraf tiruan. Metode statistic mengacu pada perhitungan probabilitas keanggotan satu objek pada group atau kelas tertentu. Pohon keputusan (Decision Tree ) adalah pemetaan mengenai alternatif-alternatif pemecahan masalah yang dapat diambil dari suatu masalah. Pohon tersebut juga memperlihatkan faktor-faktor kemungkinan/probablitas yang akan mempengaruhi alternatif-alternatif keputusan tersebut, disertai dengan estimasi hasil akhir yang akan didapat bila kita mengambil alternatif keputusan tersebut. Jaringan Syaraf Tiruan adalah Jaringan Saraf Tiruan (JST) atau Artificial Neural Network adalah suatu metode komputasi yang meniru sistem jaringan saraf biologis. Metode ini menggunakan elemen perhitungan non-linier dasar yang disebut neuron yang diorganisasikan sebagai jaringan yang saling berhubungan, sehingga mirip dengan jaringan saraf manusia. Jaringan saraf tiruan dibentuk untuk memecahkan suatu masalah tertentu seperti pengenalan pola atau klasifikasi karena proses pembelajaran. Jaringan saraf tiruan, seperti manusia, belajar dari suatu contoh karena mempunyai karakteristik yang adaptif yaitu dapat belajar dari data-data sebelumnya dan mengenal pola data yang selalu berubah. Selain itu, Jaringan Saraf Tiruan merupakan sistem yang tidak terprogram, artinya semua keluaran atau kesimpulan yang ditarik oleh jaringan didasarkan pada pengalamannya selama mengikuti proses pembelajaran/pelatihan.

\section{Literatur Review}

Analisis tinjauan literature review ditunjukkan pada tabel 1. Review Paper. Penelitian yang dilakukan oleh Ardi Hidayat, 2019 mendiagnosa penyakit tanaman jagung. Algoritma yang digunakan Convolutional Neural Network (CNN). Mengidentifikasi tiga jenis penyakit yaitu Commont Rust, Gray Leaf Spot dan Northern Leaf Blight. Akurasi yang didapat sebesar 99\%.[1]

Penelitian yang dilakukan oleh Pedro Furtado,2019 studi perbandingan akurasi mengenali makanan antara Human Visual System dengan Algoritma CNN. Penggunaan algortima CNN dapat meningkatkan kemampuan dalam mengenali obyek, karena mampu menyandikan ratusan ribu makanan dengan penampilan yang sangat berbeda [8]

Xihai Zang 2018 melakukan penelitian dengan menggunakan dua model Convolutional Neural Network yaitu model GoogLeNet dan Cifar10 untuk melakukan Identifikasi dan diagnosis otomatis penyakit dari sembilan jenis gambar daun jagung. Model GoogLeNet mencapai akurasi identifikasi rata-rata $98,9 \%$, dan model Cifar10 mencapai akurasi rata-rata $98,8 \% .[13]$

Chenyi Chen,2017 menggunakan Algoritma R-CNN yang ditambahkan dengan Context Model dan Small Region Proposal Generator meningkatkan presisi rata-rata sebesar 29,8\% dari algoritma R-CNN asli untuk mendeteksi objek kecil [3].

Sharada P. 2016 mengidentifikasi gambar daun tanaman yang sakit dan sehat dari 14 spesies tanaman dan 26 penyakit Metode Deep Convolusional Neural Network. Akurasi yang didapat sebesar 99,35\%.[11] 
M.Ridwan, 2018, mendeteksi kerusakan pada daun yang diimplementasikan dalam bentuk aplikasi dengan menggunakan pengolahan citra digital, transformasi ke citra HSL dilakukan dengan mengambil range warna daun yang tidak rusak. Diubah menjadi citra biner dengan nilai threshold sebesar 150, agar mendapatkan keseluruhan bentuk daun. Peritungan Persentase kerusakan dilakukan dengan cara menghitung jumlah piksel pada citra biner dikurangi dengan jumlah piksel citra HSL.[6]

Sarngadi Palgunadi, 2014, menggunakan file foto (image) daun mangga madu berjumlah 50 foto untuk penelitian dan 10 foto untuk testing atau pengujian. Penelitian dilakukan untuk menghasilkan klasifikasi dengan beberapa cluster yang mewakili tingkat kesehatan daun, serta memiliki vektor ciri dari masing-masing cluster. Tehnik yang dilakukan adalah Pengelompokan (clustering) dilakukan dengan Complete Linkage Clustering pada sample matriks yang berisi masing-masing indeks warna RGB. Hasil clustering tersebut menghasilkan klasifikasi menjadi beberapa cluster pada masing-masing warna RGB.[9]

Tabel 1. Review Paper

\begin{tabular}{|c|c|c|c|c|c|c|c|}
\hline $\begin{array}{l}\mathbf{N} \\
\mathbf{0}\end{array}$ & Judul Paper & Penulis & Tahun & Dimuat di & $\begin{array}{c}\text { Tujuan } \\
\text { Penelitian }\end{array}$ & Luaran/Hasil & Metode \\
\hline 2 & $\begin{array}{l}\text { Human } \\
\text { Visual } \\
\text { System vs } \\
\text { Convolution } \\
\text { Neural } \\
\text { Networks in } \\
\text { Food } \\
\text { Recognition } \\
\text { Task: An } \\
\text { Empirical } \\
\text { Comparison }\end{array}$ & $\begin{array}{l}\text { Pedro } \\
\text { Furtado, } \\
\text { Manuel } \\
\text { Caldeira, } \\
\text { Pedro } \\
\text { Martins }\end{array}$ & $\begin{array}{l}201 \\
9\end{array}$ & $\begin{array}{l}\text { Computer } \\
\text { Vision and } \\
\text { Image } \\
\text { Understanding } \\
\text {, Vol 191 Feb, } \\
2020 \text {. Elsevier }\end{array}$ & $\begin{array}{l}\text { Menganalisis } \\
\text { Human Visual } \\
\text { System (HVS) } \\
\text { dibandingkan } \\
\text { dengan } \\
\text { Convolution } \\
\text { Neural Networks } \\
\text { (CNN) dalam } \\
\text { tugas sederhana } \\
\text { pengenalan } \\
\text { makanan. }\end{array}$ & $\begin{array}{l}\text { CNN yang } \\
\text { diuji masih } \\
\text { tidak sebagus } \\
\text { HVS manusia } \\
\text { dalam } \\
\text { mengenali } \\
\text { kategori } \\
\text { makanan } \\
\text { dalam kondisi } \\
\text { yang sama } \\
\text { persis dengan } \\
74,5 \% \\
\text { berbanding } \\
80 \% \text {. jika } \\
\text { Tetapi diatih dengan } \\
\text { dilatih } \\
\text { ratusan } \\
\text { gambar dari } \\
\text { setiap kategori } \\
\text { dan sejumlah } \\
\text { kecil kategori } \\
\text { (16 dalam } \\
\text { percobaan), } \\
\text { CNN menjadi } \\
\text { cukup akurat } \\
\text { (90\% akurasi) } \\
\text { Jika CNN } \\
\text { harus } \\
\text { mempelajari } \\
\text { lebih banyak } \\
\text { kategori } \\
\text { makanan, } \\
\text { akurasi } \\
\text { berkurang } \\
\text { secara } \\
\text { substansial } \\
\text { (hingga ketika } \\
\text { harus mempelajari } \\
\text { mempategori } \\
256 \text { makanan, } \\
\text { meskipun } \\
\text { memiliki } \\
\text { ganyak }\end{array}$ & $\begin{array}{l}\text { Metode: } \\
\text { Convolutional } \\
\text { Neural Network }\end{array}$ \\
\hline
\end{tabular}




\begin{tabular}{|c|c|c|c|c|c|c|c|}
\hline $\begin{array}{l}\mathbf{N} \\
\mathbf{0}\end{array}$ & Judul Paper & Penulis & Tahun & Dimuat di & $\begin{array}{c}\text { Tujuan } \\
\text { Penelitian }\end{array}$ & Luaran/Hasil & Metode \\
\hline & & & & & & \multicolumn{2}{|l|}{ pelatihan). } \\
\hline 3 & $\begin{array}{l}\text { Identification } \\
\text { of Maize Leaf } \\
\text { Diseases } \\
\text { Using } \\
\text { Improved } \\
\text { Deep } \\
\text { Convolutional } \\
\text { Neural } \\
\text { Networks }\end{array}$ & $\begin{array}{l}\text { Xihai } \\
\text { Zhang, Yue } \\
\text { Qiao, } \\
\text { Fanfeng } \\
\text { Meng, } \\
\text { Chengguo } \\
\text { Fan } \\
\text { Minging } \\
\text { Zhang }\end{array}$ & $\begin{array}{l}201 \\
8\end{array}$ & $\begin{array}{l}\text { IEEE Access } \\
\text { Volume : } 6\end{array}$ & $\begin{array}{l}\text { Identifikasi dan } \\
\text { diagnosis } \\
\text { otomatis penyakit } \\
\text { dari } 9 \text { jenis } \\
\text { gambar daun } \\
\text { jagung }\end{array}$ & $\begin{array}{l}\text { Model } \\
\text { GoogLeNet } \\
\text { mencapai } \\
\text { akurasi } \\
\text { identifikasi } \\
\text { rata-rata top-1 } \\
98,9 \% \text {, dan } \\
\text { model Cifar10 } \\
\text { mencapai } \\
\text { akurasi rata- } \\
\text { rata } 98,8 \% \text {. }\end{array}$ & $\begin{array}{l}\text { Menggunakan } 2 \\
\text { model } \\
\text { Convolutional } \\
\text { Neural Network } \\
\text { yaitu model } \\
\text { GoogLeNet dan } \\
\text { Cifar10 }\end{array}$ \\
\hline 4 & $\begin{array}{l}\text { R-CNN for } \\
\text { Small Object } \\
\text { Detection }\end{array}$ & $\begin{array}{l}\text { Chenyi } \\
\text { Chen, } \\
\text { Ming-Yu } \\
\text { Liu, Oncel } \\
\text { Tuzel and } \\
\text { Jianxiong } \\
\text { Xiao }\end{array}$ & $\begin{array}{l}201 \\
7\end{array}$ & $\begin{array}{l}\text { Springer } \\
\text { International } \\
\text { Publishing AG } \\
2017\end{array}$ & $\begin{array}{l}\text { Mengatasi } \\
\text { masalah pada } \\
\text { deteksi obyek } \\
\text { kecil }\end{array}$ & $\begin{array}{l}\text { Algoritma R- } \\
\text { CNN yang } \\
\text { ditambahkan } \\
\text { dengan } \\
\text { Context } \\
\text { model dan } \\
\text { small region } \\
\text { proposal } \\
\text { generator } \\
\text { meningkatka } \\
\text { n presisi rata- } \\
\text { rata sebesar } \\
29,8 \% \\
\text { algoritma R- } \\
\text { CNN asli } \\
\text { untuk } \\
\text { mendeteksi } \\
\text { objek kecil. }\end{array}$ & $\begin{array}{l}\text { Algoritma R- } \\
\text { CNN yang } \\
\text { ditambahkan } \\
\text { dengan Context } \\
\text { Model dan } \\
\text { Small Region } \\
\text { Proposal } \\
\text { Generator }\end{array}$ \\
\hline 5 & $\begin{array}{l}\text { Using Deep } \\
\text { Learning for } \\
\text { Image-Based } \\
\text { Plant } \\
\text { Diseaase } \\
\text { Detection }\end{array}$ & $\begin{array}{l}\text { Sharada P. } \\
\text { Mohanty, } \\
\text { David } \\
\text { P.Hughes, } \\
\text { Marcel } \\
\text { Salathe }\end{array}$ & $\begin{array}{l}201 \\
6\end{array}$ & $\begin{array}{l}\text { Journal } \\
\text { Frontiers in } \\
\text { Plant Science }\end{array}$ & $\begin{array}{l}\text { Identifikasi } \\
\text { gambar daun sakit } \\
\text { dan sehat dari } 14 \\
\text { spesies tanaman } \\
\text { dan } 26 \text { penyakit }\end{array}$ & $\begin{array}{l}\text { Akurasi yang } \\
\text { didapat } \\
\text { sebesar } \\
99,35 \%\end{array}$ & $\begin{array}{l}\text { Dataset }= \\
54.306 \text { gambar } \\
\text { Metode Deep } \\
\text { Convolusional } \\
\text { Neural Network. }\end{array}$ \\
\hline 6 & $\begin{array}{l}\text { Aplikasi } \\
\text { Pendeteksi } \\
\text { Kerusakan } \\
\text { Pada Daun } \\
\text { Berdasarkan } \\
\text { Warna }\end{array}$ & $\begin{array}{l}\text { M Ridwan } \\
\text { Dwi } \\
\text { Septian, } \\
\text { Margi } \\
\text { Cahyanti, } \\
\text { Ericks } \\
\text { Rachmat } \\
\text { Swedia }\end{array}$ & $\begin{array}{l}201 \\
8\end{array}$ & $\begin{array}{l}\text { Konferensi } \\
\text { Nasional } \\
\text { Sistem } \\
\text { Informasi } 2018\end{array}$ & $\begin{array}{l}\text { mendeteksi } \\
\text { kerusakan pada } \\
\text { daun yang } \\
\text { diimplementasika } \\
\mathrm{n} \text { dalam bentuk } \\
\text { aplikasi dengan } \\
\text { menggunakan } \\
\text { pengolahan citra }\end{array}$ & $\begin{array}{l}\text { Uji coba } \\
\text { menggunakan } \\
10 \text { data citra } \\
\text { daun mangga. } \\
\text { Citra uji coba } \\
\text { diambil } \\
\text { berukuran } 100 \\
\text { x } 56 \\
\text { Aplikasi telah } \\
\text { berhasil } \\
\text { mengeluarkan } \\
\text { output berupa } \\
\text { persentase } \\
\text { kerusakan } \\
\text { pada daun. }\end{array}$ & $\begin{array}{l}\text { transformasi ke } \\
\text { citra HSL } \\
\text { dengan } \\
\text { mengambil } \\
\text { range warna } \\
\text { daun yang tidak } \\
\text { rusak. Diubah } \\
\text { menjadi citra } \\
\text { biner dengan } \\
\text { threshold } \\
\text { sebesar 150, } \\
\text { agar } \\
\text { mendapatkan } \\
\text { keseluruhan } \\
\text { bentuk daun. } \\
\text { persentase } \\
\text { kerusakan } \\
\text { dilakukan } \\
\text { dengan cara } \\
\text { menghitung } \\
\text { jumlah piksel } \\
\text { pada citra biner } \\
\text { dikurangi } \\
\text { dengan jumlah } \\
\text { piksel citra } \\
\text { HSL. }\end{array}$ \\
\hline 7 & $\begin{array}{l}\text { Klasifikasi } \\
\text { Kualitas } \\
\text { Kesehatan } \\
\text { Daun } \\
\text { Mangga } \\
\text { Berdasarkan } \\
\text { Warna Citra }\end{array}$ & $\begin{array}{l}\text { Sarngadi } \\
\text { Palgunadi, } \\
\text { Yulandita } \\
\text { Almandaty } \\
\text { a }\end{array}$ & $\begin{array}{l}201 \\
4\end{array}$ & $\begin{array}{l}\text { Prosiding } \\
\text { SNST ke-5 } \\
\text { Tahun } 2014 \\
\text { Fakultas } \\
\text { Teknik } \\
\text { Universitas } \\
\text { Wahid Hasyim }\end{array}$ & $\begin{array}{l}\text { Menghasilkan } \\
\text { klasifikasi dengan } \\
\text { beberapa cluster } \\
\text { yang mewakili } \\
\text { tingkat } \\
\text { kesehatan daun, } \\
\text { serta memiliki }\end{array}$ & $\begin{array}{l}\text { file foto } \\
\text { (image) daun } \\
\text { mangga madu } \\
\text { berjumlah } 50 \\
\text { foto untuk } \\
\text { penelitian dan } \\
10 \text { foto untuk }\end{array}$ & $\begin{array}{l}\text { Pengelompoka } \\
\mathrm{n} \text { (clustering) } \\
\text { dilakukan } \\
\text { dengan } \\
\text { Complete } \\
\text { Linkage } \\
\text { Clustering pada }\end{array}$ \\
\hline
\end{tabular}




\begin{tabular}{|c|c|c|c|c|c|c|c|}
\hline $\begin{array}{l}\mathbf{N} \\
\mathbf{O}\end{array}$ & Judul Paper & Penulis & Tahun & Dimuat di & $\begin{array}{c}\text { Tujuan } \\
\text { Penelitian }\end{array}$ & Luaran/Hasil & Metode \\
\hline & Daun & & & Semarang & $\begin{array}{l}\text { vektor ciri dari } \\
\text { masing-masing } \\
\text { cluster }\end{array}$ & $\begin{array}{l}\text { testing atau } \\
\text { pengujian. }\end{array}$ & $\begin{array}{l}\text { sample } \\
\text { matriks yang } \\
\text { berisi masing- } \\
\text { masing indeks } \\
\text { warna RGB. } \\
\text { Hasil clustering } \\
\text { tersebut } \\
\text { menghasilkan } \\
\text { klasifikasi } \\
\text { menjadi } \\
\text { beberapa } \\
\text { cluster pada } \\
\text { masing-masing } \\
\text { warna RGB }\end{array}$ \\
\hline
\end{tabular}

Sumber : Hasil Penelitian (2020)

Dari hasil tinjauan literatur sistematis yang telah dilakukan terdapat pertanyaan penelitian (Research Question/RQ ) yang dibuat untuk mengidentifikasikan masalah penelitian sebagai berikut : 1) RQ1 : Metode Citra Digital apa yang dapat digunakan dengan optimal untuk mengekstraksi fitur penyakit daun 2) RQ2: Metode klasifikasi apa yang dapat digunakan secara efisien untuk mengklasifikasikan jenis penyakit pada daun.

Sedangkan untuk tujuan penelitian (Research Objective) yang sesuai yang terkait dengan penelitian ini adalah : 1) RO1 : Menentukan Metode Citra digital yang dapat digunakan dengan optimal untuk mengekstraksi fitur penyakit daun Mangga 2) RO2: Metode klasifikasi yang dapat digunakan secara efisien untuk mengklasifikasikan jenis penyakit pada daun Mangga

\section{Kesimpulan}

Metode Citra Digital yang dapat digunakan dalam identifikasi penyakit pada daun mangga adalah tahapan Image Acquisition, Preprocessing, Segmentation, Ekstraksi Fitur, Seleksi Fitur. Metode Klasifikasi yang dapat digunakan adalah SVM, Artificial Neural Network, Decision Tree, Convolutional Neural Network.

\section{Referensi}

[1] Ardi H.,Ucuk D.,Irmawati (2019). Detection of Disease on Corn Plant Using Convolutional Neural Network Methods. Journal of a Science and Information Vol 12. No.1

[2] Budi Daya Desa. Hama dan Penyakit Pada Tanaman Mangga. https://budidaya desa.blogspot.com/2014/12/teknik-cara-budidaya-mangga-mangifera.html

[3] Chen., Ming-Yu., Tuzel \& Xiao (2017). R-CNN for Small Object Detection. Springer International Publishing AG 2017.

[4] Intan Permata Sari, Bambang Hidayat, Ratri Dwi Atmaja.(2016). Perancangan dan Simulasi Deteksi Penyakit Tanaman Jagung Berbasis Pengolahan Citra Digital Menggunakan Metode Color Moments dan GLCM. Seminar Nasional Inovasi dan Aplikasi Teknologi di Industri (SENIATI).

[5] Layanan Informasi Desa. Penyakit utama pada tanaman mangga. https://8villages.com/full/petani/article/id/5c244d5459678e677c05aead

[6] M Ridwan Dwi Septian, Margi Cahyanti, Ericks Rachmat Swedia. (2018). Aplikasi Pendeteksi Kerusakan Pada Daun Berdasarkan Warna. Konferensi Nasional Sistem Informasi 2018.

[7] Madenda, S (2015). Pengolahan Citra dan Video Digital. Penerbit Erlangga

[8] Pedro F.,Manuel C., Pedro M. (2019). Human Visual System vs Convolution Neural Networks in Food Recognition Task: An Empirical Comparison. Computer Vision and Image Understanding, Vol 191 Feb, 2020. Elsevier

[9] Sarngadi Palgunadi,Yulandita Almandatya.(2014). Klasifikasi Kualitas Kesehatan Daun Mangga Berdasarkan Warna Citra Daun. Prosiding SNST ke-5 Tahun 2014 Fakultas Teknik Universitas Wahid Hasyim Semarang.

[10] Setiyono, Andik. Literatur Review, https://core.ac.uk/reader/35372382.

[11] Sharada P. Mohanty., David P.Hughes., Marcel S. (2016). Using Deep Learning for ImageBased Plant Diseaase Detection. Journal Frontiers in Plant Science. 
[12] Subdirektorat Publikasi dan Kompilasi Statistik, Statistika Tanaman Buah-buahan dan Sayuran Tahunan Indonesia 2018, Badan Pusat Statistik Indonesia.

[13] Xihai Z., Yue Q., Fanfeng M., Cheng., Minging. (2018). Identification of Maize Leaf Diseases Using Improved Deep Convolutional Neural Networks. IEEE Access Volume : 6. 